\section{TRIASSIC CEPHALOPODS.}

$A$ LL who are interested in the invertebrata of the Trias A will be pleased to see the supplement recently issued to "Die Cephalopoden der Hallstätter Kalke," by Dr. Edmund Mojsisovics (Abhandlungen der k.k. Geologischen Reichsanstalt, Band vi., I902). The first volume of this detailed and beautifully illustrated memoir, published in 1873 and 1875 , contained 174 pages of text and 70 finely executed lithographic plates. The second volume appeared in 1893 , and extended to 835 pages and 130 plates. The part now published is a supplement to the first volume, and continues the paging from 175 to 356 , while the plates are numbered from $I$ to 23 as supplementary. It is somewhat difficult for geologists familiar only with the English Trias to realise the richness of the fauna described in this memoir, which, for the sufficient illustration of the Cephalopoda alone, needs 223 large quarto plates. The author speaks in the preface of the somewhat primitive nomenclature of the earlier parts of the first volume, but the most forward student will have nothing to complain of in this direction in the present supplement, unless it be the use of such impossible names as Pompeckjites. Some interesting remarks are made on the subdivisions now adopted for the "Hallstätter Kalke," and a table of these is given on p. 345 . Among the forms of Cephalopods here described, none perhaps are more remarkable than the primitive types included in the Belemnitidæ. In transitional deposits such as the Trias one expects to find the lingering of antique forms and the foreshadowing of types yet to come; but it is a little startling to find the Carboniferous genus Pleuronautilus so nearly associated with such forms as Rhacophyllites, which so strongly reminds us of the Liassic Phylloceras heterophyllus. The author is to be congratulated on the successful completion of this monumenta work, which has engaged his attention for so many years, and, by this supplement, is brought fully abreast of the present time.

\section{UNIVERSITY AND EDUCATIONAL. INTELLIGENCE.}

OXForv. The Romanes lecture will be delivered by Sir Oliver J. Lodge, F.R.S., in the Sheldonian Theatre on Friday, June 12, at $5 \mathrm{p} . \mathrm{m}$. The subject of the lecture is "Modern Views on Matter."

On Saturday last Prof. Tylor, F.R.S., was elected an honorary fellow of Balliol College, of which he has been a member since his appointment as Keeper of the University Museum and reader in anthropology in 1883 .

Last week's Gasette contained the report of the museum delegates for 1902. Considerable additions have been made, particularly to the Pitt Rivers and Hope collections. An important change in administration took place after Prof. Tylor resigned the keepership, this office being abolished and replaced by a secretary to the museum delegates. Prof. Miers, F.R.S., was appointed to the new position. During the past $y$-ar three new laboratories have been added to the chemical department, and an electric installation has been put into the museum

The Junior Scientific Club held a conversazione in the museum on the evening of Tuesday, May 26 . Lectures were given by Sir David Salomons, Bart., on " Motor Cars," by Prof. Arthur Thomson on "Man's Cranial Form," and by Prof. Miers on "Klondyke." Among the exhibits were an excellent demonstration of the properties of radium by Mr. F. Soddy, a show of collotype and three-colour printing from the Clarendon Press, an improved form of capillary electrometer by Mr. H. S. Souttar, photographs of the new star in Gemini by Prof. Turner, a collection of living British fresh-water fish by Mr. Morison, a demonstration of the principles of wireless telegraphy by Mr. Littlehailes and Mr. Lattey, and a collection of apparatus from the Cambridge Scientific Instrument Company and the Magdalen College Laboratory.

CAmbridgF.-Dr. Chase, president of Queens' College, has been re-elected Vice-Chancellor for the ensuing academical year.

Mr. F. W. W. Griftin, King's, has been appointed to the No. 1753 , VOL. 68] university table in the Plymouth Marine Biological Laboratory.

In the mathematical tripos, part i., sixty-five men and eighteen women have acquitted themselves so as to deserve mathematical honours.

The memoirs of $\mathrm{Mr}$. J. Parkinson, advanced student of St. John's College, on the geology of Tintagel and Davidstow, and on the rocks of Guernsey, have been adjudged to be "of distinction as a record of original research."

Dr. Tilomas Slater Price has been nominated to succeed Mr. Woodward as director of chemical studies at the Birmingham Municipal Technical School.

$A_{N}$ exhibition of practical work executed by candidates at the technological and manual training examinations of the City and Guilds Institute will be opened at the Imperial Institute on Thursday, June $\mathrm{xI}$, at $3 \mathrm{p} . \mathrm{m}$., by the Marquess of Londonderry, K.G.

Science announces that Prof. William $\mathrm{H}$. Brewer has resigned the professorship of agriculture at Yale University and has been appointed professor emeritus. At Cornell University Prof. T. F. Hunt, dean of the Agricultural College, of the Ohio State University, has been appointed professor of agronomy, and Dr. B. F. Kingsbury has been appointed assistant professor of embryology.

ON the occasion of the commemoration day proceeding at Livingstone College, Leyton, on June ro, the Bishop of St. Albans will preside. Livingstone College has rendered valuable services, not only to missionaries, but also to many travellers in unhealthy regions, and it is hoped that the present opportunity will lead to much greater interest being taken in the work carried on under its auspices.

IT is worthy of note that in connection with a short course of popular lectures on nature-study just given by $\mathrm{Mr}$. C. Carus-Wilson at Ramsgate and Margate, excursions were arranged to places of geological interest in the neighbourhood. Field-work and personal observation of natural objects and phenomena are essential in the study of nature, and it is to be hoped that wherever popular lectures are given on natural science subjects, outdoor work will be arranged in connection with them.

THE draft charters incorporating universities in Manchester and Liverpool have, the Times reports, been approved by the Privy Council and laid before Parliament. In the case of Manchester, the charter provides that the University shall be called "the Victoria University of Manchester." A description is given of the powers conferred upon the University relating to such matters as the granting and conferring of degrees, the granting of diplomas, the provision of instruction in such branches of learning as the University may think fit, the examination and inspection of schools, and the affiliation of other institutions. The authorities of the University will be the Chancellor, the Vice-Chancellor, two Pro-Vice-Chancellors, the Court, the Council, the Senate, the Board of Faculties, and the Convocation, besides a treasurer and other proper officers. In the case of Liverpool, the charter provides that the University shall be known as "the University of Liverpool." It is provided that Lord Derby shall be the first Chancellor of the University, and Mr. A. W. W. Dale, now principal of University College, Liverpool, the first Vice-Chancellor. The supreme governing body of the University is to be the Court, and the governing body and executive of the University is to be the council; and the Senate, consisting of the Vice-Chancellor, the deans of all the faculties, all the professors of the University, and the librarian, will, subject to the statutes of the University and the control and approval of the council, regulate and superintend the education and discipline of the University.

IT is announced in the Times of May 28 that the council of the Yorkshire College has agreed upon the principles upon which the charter for the proposed new Yorkshire University should be based. These are that the Yorkshire College be merged in the University; that the University be founded on a non-federal basis, but that it be empowered to affiliate other institutions; and that the University be governed by a court of governors and by an executive 
council. Substantial agreement has been arrived at between the three colleges, which have constituted Victoria University, as to a common matriculation examination for all the three Universities of Yorkshire, Manchester, and Liverpool, and provision has been made for a joint board to be constituted from the three Universities to deal with the question. The additions to the staff and equipment of the college essential to the proper carrying on of an independent University will, it is thought, require a minimum additional expenditure of about joool. a year, while extensive additions will also be required to the college buildings. The coalowners of Yorkshire have decided to erect a separate building for the mining department, and have collected a sum of $5500 l$. for the purpose. The council of the college is desirous also of completing the main block of the college and it is estimated that this would cost about $60,000 l$. Three friends of the college have each promised $5000 l$., while a fourth has promised $2000 l$. The Clothworkers' Company of London offers to transfer to the new University as its absolute property the whole of the buildings and equipment of the textile industries, dyeing and art departments, which are at present held in trust by the college for the Clothworkers' Company. Attached to the offer is a condition that these departments shall be recognised as integral parts of the University. The Company has also promised to grant in perpetuity to the University for the maintenance of these departments an annual sum of not less than $4000 l$. This means a gift to the University of a capitalised sum of upwards of $200,000 l$.

WE learn from the Pioneer Mail that the Government of India has addressed to the Bombay Government a long letter on the subject of the proposed Tata endowment of a research institute for India. It is in the main an explanation of the delay of four years which has occurred in giving effect to the scheme. As has been already explained in these columns, the scheme owes its origin to the munificent intentions of Mr. J. N. Tata, who in 1896 proposed to vest in trustees properties in Bombay, representing a capital of thirty lakhs of rupees, in order that the net income, amounting to some 8 oool., might be applied towards the endowment of a research institute for India. The proposal soon assumed the form of an Imperial teaching university, intended to train Indian graduates in scientific research, to confer degrees, and to select the best students for further training in Europe and America. Mr. Tata was later asked to consider whether the original scheme was not too ambitious, and whether it might not be proceeded with, so far as funds permitted, leaving the further development to come with the growth of income. Mr. Tata met a small conference of educational experts, and with them defined the general principles to be kept in view in launching the scheme. Sir William Ramsay was invited to visit India to advise, and the help of other experts was obtained. Much delay has been caused by a consideration of numerous recommendations received, but we are glad to know that financial difficulties appear to have been overcome, and that legislation will probably soon follow with a view to provide India with an institution for higher scientific instruction. The institute is to be located at Bangalore, and the Mysore durbar, in addition to making a free grant of land, has undertaken to contribute $3333 l$. per annum for a period of ten years. The Government of India is prepared to make a similar annual subsidy. This will raise the income to $15,000 l$. per annum, which exceeds by roool. the highest estimate of necessary expenditure framed by Sir William Ramsay. The Government also proposes to contribute one lakh of rupees towards the cost of the construction and equipment of the necessary buildings. The institute is to comprise a department of chemistry, a department of experimental physics, and a department of experimental biology.

\section{SOCIETIES AND ACADEMIES.} LONDON.

Royal Society, May 14.-"The Combination of Hydrogen and Chlorine under the Influence of Light." By P. V. Bevan. Communicated by Prof. J. J. Thomson, F.R.S

The first point studied in this investigation was the initial expansion, or Draper effect, when light is allowed to fall on a mixture of hydrogen and chlorine. This expansion was shown to be due to heat developed by the combination of the hydrogen and chlorine to form hydrochloric acid. The heat effect was measured by the change in resistance observed in a fine platinum wire sealed through the buib in which the gas mixture was exposed to light. The investigation then considers the period of induction of Bunsen and Roscoe, and the effects of various intensities of light on the rate of combination. Experiments were also made on the effect of illuminating chlorine before mixing with hydrogen, and the original observation of Draperthat the combination takes place more readily after this preillumination-was confirmed. If, however, the gases be bubbled through water after preillumination of chlorine, this effect is destroyed, and the gases behave like the ordinary mixture. To obtain evidence of an intermediate compound, the gases were submitted to sudden expansion producing supersaturation. When the gases were dust free a nucleus-forming substance occurred after illumination, so that on the expansion a cloud was formed when the supersaturation reached a certain amount. In the non-illuninated gas mixture no cloud-producing substance could be observed with yellow light. This cloud is produced in chlorine alone. In the mixture of hydrogen and chlorine the cloud appears before any hydrochloric acid is formed. The theoretical part of the paper considers the action as taking place in three stages, combination to form complex molecules containing hydrogen chlorine and water molecules occurring, and then a break down of this complex system giving hydrochloric acid and water. The view thus taken explains the chief features of the induction period, and can be extended to apply to other similar actions where a catalyser is necessary for the progress of the action.

"On the Photo-electric Discharge from Metallic Surfaces in Different Gases." By W. Mansergh Varley, M.Sc., Ph.D. Communicated by Prof. J. J. Thomson, F.R.S

The object of the experiments was to study the effect of the pressure and nature of the gas with which a naetal surface is surrounded upon the magnitude of the photoelectric current from that surface, the method used being to draw the complete curves connecting the current and the potential difference at each pressure or in each gas examined, keeping the intensity of the ultra-violet illumination and the other conditions unaltered.

A suitable source of ultra-violet light which would remain constant in intensity while long series of observations were being taken was ultimately found in the spark between iron terminals in an atmosphere of pure dry hydrogen. The spark gap was in parallel with three Leyden.jars in the secondary circuit of an induction coil used as a transformer. The photo-electric currents were measured from a metal surface placed a few millimetres behind a fine gauze, through which the light passed, and which served as the positive electrode. A brass vessel, with a quartz window to admit the light, served to contain the electrodes.

Series of curves were obtained showing the relation between the photo-electric current and the potential at pressures ranging from $760 \mathrm{~mm}$. to $0.0014 \mathrm{~mm}$. They show that down to pressures of about $\mathrm{I} \mathrm{mm}$. no true saturation currents exist, the currents always increasing with the potential, but less rapidly for a certain range of potential gradients than for lower or higher potential gradients, while at pressures below the critical pressure true saturation currents exist.

Curves connecting the potentials and corresponding photoelectric currents in air, carbon dioxide, hydrogen and carbon monoxide at various pressures were also obtained, and it was shown that the curves could all be explained on the ionic theory of conduction, both qualitatively and quantitatively. Zinc, platinum and aluminium electrodes were employed.

" On the Discovery of a Species of Trypanosoma in the Cerebro-spinal Fluid of Cases of Sleeping Sickness." By Aldo Castellani, M.D. Communicated by the Malaria Committee of the Royal Society.

The author states that he has found trypanosomes to be present in the cerebro-spinal fluid in twenty out of thirtyfour cases of sleeping sickness examined; in two of the cases trypanosomes were also found in the lateral ventricles, and in one in the blood taken from the finger. The cerebro-spinal fluid was obtained by lumbar puncture, and as the trypanosomes are not numerous, it was first centri- 